\title{
Above-ground woody biomass allocation and within tree carbon and nutrient distribution of wild cherry (Prunus avium L.) - a case study
}

\author{
Christopher Morhart ${ }^{*}$ (D, Jonathan P. Sheppard, Johanna K. Schuler and Heinrich Spiecker
}

\begin{abstract}
Background: The global search for new ways to sequester carbon has already reached agricultural lands. Such land constitutes a major potential carbon sink. The production of high value timber within agroforestry systems can facilitate an in-situ carbon storage function. This is followed by a potential long term ex- situ carbon sinkwithin long lasting products such as veneer and furniture. For this purpose wild cherry (Prunus avium L.) is an interesting option for middle Europe, yielding high prices on the timber market.

Methods: A total number of 39 wild cherry were sampled in 2012 and 2013 to assess the leafless above ground biomass. The complete trees including stem and branches were separated into $1 \mathrm{~cm}$ diameter classes. Wood and bark from sub-samples were analysed separately and nutrient content was derived. Models for biomass estimation were constructed for all tree compartments.

Results: The smallest diameter classes possess the highest proportion of bark due to smaller cross sectional area. Tree boles with a greater amount of stem wood above $10 \mathrm{~cm}$ in diameter will have a more constant bark proportion. Total branch bark proportion also remains relatively constant above $d_{1.3 \mathrm{~m}}$ measurements of $8 \mathrm{~cm}$. A balance is evident between the production of new branches with a low diameter and high bark proportion offset by the thickening and a relative reduction in bark proportion in larger branches. The results show that a single tree with an age of 17 and 18 years can store up to $85 \mathrm{~kg}$ of carbon within the aboveground biomass portion, an amount that will increase as the tree matures. Branches display greater nutrient content than stem sections per volume unit which can be attributed to a greater bark proportion.

Conclusions: Using the derived models the carbon and the nutrient content of above-ground woody biomass of whole trees can be calculated. Suggested values for carbon with other major and minor nutrients held within relatively immature trees strongly supports the idea of the inclusion of wild cherry within agroforestry systems as an option for carbon sequestration.
\end{abstract}

Keywords: Carbon sequestration, Biomass, Bark, Branch, Stem, Nutrient content, Allometry, Agroforestry

\footnotetext{
* Correspondence: christopher.morhart@iww.uni-freiburg.de

Chair of Forest Growth and Dendroecology, Albert-Ludwigs-University

Freiburg, Tennenbacher Str. 4, D- 79106 Freiburg, Germany
} 


\section{Background}

The period from 1983 to 2012 has been the warmest 30year period of the last 1400 years in the Northern Hemisphere (IPCC 2014). The increase of anthropogenic greenhouse gas (GHG) emissions has especially occurred in the last decades, approximately half of the anthropogenic $\mathrm{CO}_{2}$ emissions contributing to the increase between 1750 and 2011 have occurred in the last 40 years (IPCC 2014). Consequently, to counteract this rise there are three major forest management activities that can help reduce atmospheric carbon, namely; carbon sequestration, carbon conservation and carbon substitution (Montagnini and Nair 2004). The global search for new ways to sequester carbon has already reached agricultural lands. Such land constitutes a major potential sink and could sequester large quantities of carbon. Aside from suggested options for adapted cultures and management systems the high potential of agroforestry systems (AFS) has recently been raised (Albrecht and Kandji 2003; Masera et al. 2003; Makundi and Sathaye 2004; Sharrow and Ismail 2004; Montagnini and Nair 2004; Peichl et al. 2006; Nair et al. 2009; Nair et al. 2010). These systems facilitate the production of trees under short rotations as well as the production of high valuable timber on agricultural land. By harvesting this timber, in-situ carbon storage is followed by a long term storage potential as ex-situ carbon storage. Such carbon storage consists of long lasting products such as veneer and furniture.

Farmers and land managers are often reluctant to implement AFS due to additional shade cast and subsequent nutrient export brought about by the culture of trees above annual crops. To date, beneficial or disadvantageous effects of AFS with a focus on the production of valuable wood in middle Europe to carbon and nutrient cycles have not been fully understood. Also different management measures such as pruning or harvesting exert an influence on carbon and nutrient storage and export within AFS, meanwhile, exact figures are still missing. Our idea is that AFS could be planned and managed in a more customised way towards valuable wood production, and carbon storage or nutrient recirculation, if appropriate models would be available. One of the most important valuable tree species, which can be used for the composition of AFS in middle Europe is wild cherry (Prunus avium L.) as it displays a rather fast growth and its timber can be of high value (Spiecker and Spiecker 1988; Balandier and Dupraz 1999; Morhart et al. 2014). Besides, its fruits, flowers and leaves are a food source for numerous animals and microorganisms. Wild cherry is neither a large nor long lived tree, mean dimensions are often quoted as 20 to $30 \mathrm{~m}$ in height (Evans 1984; Joyce 1998; Ducci et al. 2013), while diameters at breast height of between 50 and $90 \mathrm{~cm}$ are achievable within a 70 or 80 year rotation (Otter 1954; Evans 1984; Spiecker 2006; Ducci et al. 2013). Within published volume tables for wild cherry merchantable stem volumes are suggested to reach over $2 \mathrm{~m}^{3}$ within a full rotation (Pryor 1988; Röös 1994), or more if radial increment is greater on high productivity sites (Spiecker 1994). Carbon is widely accepted to encompass up to $50 \%$ of total woody biomass (e.g., Fang et al. 2001; Kurz et al. 2009; Pretzsch 2010). Applying such volume tables as a basis, the carbon content can be calculated utilising the density and a general conversion factor as suggested by Pretzsch (2010). This efficient approach has some limitations due to the fact that the density is acknowledged not only to differ within tree species (Hamilton 1975) and between sites (Maniatis et al. 2011), but is also recognised not to be homogenous throughout a tree (Wassenberg et al. 2015). Additionally, the carbon content is neither the same between tree species nor among tissue types (Thomas and Martin 2012). Furthermore, volume functions usually are not prepared for the prediction of wood with diameters below merchantable timber size.

Zianis et al. (2005) wrote that the estimation of tree biomass is necessary for both the sustainable planning of forest resources and for the study of energy and nutrient flows within given situations. Whole tree estimations and approaches separating only stem and branches seem not to be adequate for the detailed estimation of bark biomass, further partitioning, for example into diameter classes increase the accuracy (Adler et al. 2005; Guidi et al. 2008; Morhart et al. 2013). The nutrient content for various tree species has been quantified by a number of authors. Regarding leafless biomass, consensus maintains that bark contains more nutrients than wood tissues, in both broadleaved and coniferous species. This has been presented for various species including: Paper birch (Betula papyrifera Marshall) and subalpine fir (Abies lasiocarpa [Hooker] Nuttall) (Wang et al. 1996; Wang et al. 2000), grey alder (Alnus incana [L.] Moench) (Uri et al. 2002), silver birch (B. Pendula Roth) (Uri et al. 2007), sessile oak (Quercus petraea [Mattuschka] Liebl.), European beech (Fagus sylvatica L.) and European hornbeam (Carpinus betulus L.) (André and Ponette 2003; André et al. 2010), and with hybrid poplar (Populus spp.) (Morhart et al. 2013). The heartwood of certain species is suggested to contain low proportions of nutrients such as phosphorus and potassium while the sapwood is generally high in all primary and secondary nutrients (Wright and Will 1958). It has also been suggested that the nutrient concentrations can be two to three times greater in branches than in stem wood (Alriksson and Eriksson 1998). This can possibly be attributed to lower cross sectional diameter, thus a higher bark proportion. Branches represent the sites of active growth thus 
requiring a greater availability of nutrient for associated growth processes. Pretzsch (2010) calculated that $0.9 \mathrm{t} /$ ha $\mathrm{N}$ is stored within European beech. Of this total, $63 \%$ are stored in leaves, bark and branch wood (equating to $25 \%$ of total stand biomass). He notes that a further $37 \%$ of stand biomass is held within the merchantable timber fraction (diameter over $7 \mathrm{~cm}$ ). Furthermore, Pretzsch (2010) estimates that the harvest of the merchantable timber results in the removal of one third of $\mathrm{N}, \mathrm{P}, \mathrm{K}, \mathrm{Ca}$ and $\mathrm{Mg}$ from the site. The removal of crown portions will further exacerbate the removal of nutrients from the site. The effect of nutrient removal from forest stands through whole tree harvesting mechanisms is thoroughly reviewed by Kimmins (1977).

Models predicting the volume production potential of valuable timber of wild cherry within AFS already exist (Dagnelie et al. 1999; Alberti et al. 2006; Hackenberg et al. 2014); models predicting its carbon and nutrient storage within AFS are still missing. A combination of all models would be beneficial to customise AFS to individual targets. This study aims to provide models to predict the exact amount of biomass within different compartments of wild cherry in AFS. The allometric biomass functions for wild cherry can serve as a basis for the calculation of the stored carbon as well as the nutrient content between tree compartments and between wood and bark fractions.

\section{Methods}

\section{Description of the experimental site}

The experimental site is located in south western Germany close to Breisach $\left(48^{\circ} 4 \quad 24 \quad \mathrm{~N} ; 7^{\circ}\right.$ 3526 E, $182 \mathrm{~m}$ a.s.l.). The whole plot covers an area of 2.5 ha, is situated on the floodplain of the river Rhine and was established 1997. The climate is dominated by warm summers and mild winters. Monthly based means of air temperature and precipitation based on the 1961 to 1990 Climate Normals and actual monthly climatic conditions for the years 1997 to 2012 obtained from interpolated gridded data with a resolution of $1 \mathrm{~km} \times 1 \mathrm{~km}$ (DWD (Deutscher Wetterdienst) 2015) are shown in Fig. 1. A continuously higher mean temperature since site establishment can be observed. In contrast, monthly precipitation sums do not show a clear trend. Within this time period, the mean annual precipitation sum based on monthly values was $710 \mathrm{~mm}$ (May-Sept.: $384 \mathrm{~mm}$ ) whilst the mean annual air temperature was $11.2^{\circ} \mathrm{C}$ (May-Sept.: $18.0^{\circ} \mathrm{C}$ ). Soils consist of a derivative of windblown Rhine valley sediments known as periglacial loess. They have a high water permeability and low water storage capacity. Consequently, the upper soil layers can tend to be dry in hot dry summers, but due to the neighbouring river Rhine the water table remains high. Wild cherry is sensitive to frequent drought stress (Hemery et al. 2010; Coello et al. 2013). The high water table is not optimal for the species since it prefers moist but not waterlogged or stagnant soils (Otter 1954; Evans 1984; Pryor 1988; Savill 1991; Joyce 1998; Hemery et al. 2010; Ducci et al. 2013). These conditions may affect total biomass production. The research site is located on former agricultural land with a soil $\mathrm{pH}$ of 7.7-7.8 (Table 1), such a soil pH can be considered slightly alkaline and implies a high saturation of base cations. It is assumed that the soils are not deficient of essential nutrients needed for growth. Soil types and their freely-available nutrient composition are also shown in Table 1. Soil analysis was based on three samples and analysed in accordance with established methodologies (VDLUFA 1991).

\section{Tree population and sampling}

The research site was planted in 1997 with $1+1$ stock. The site layout was planted in a randomised block

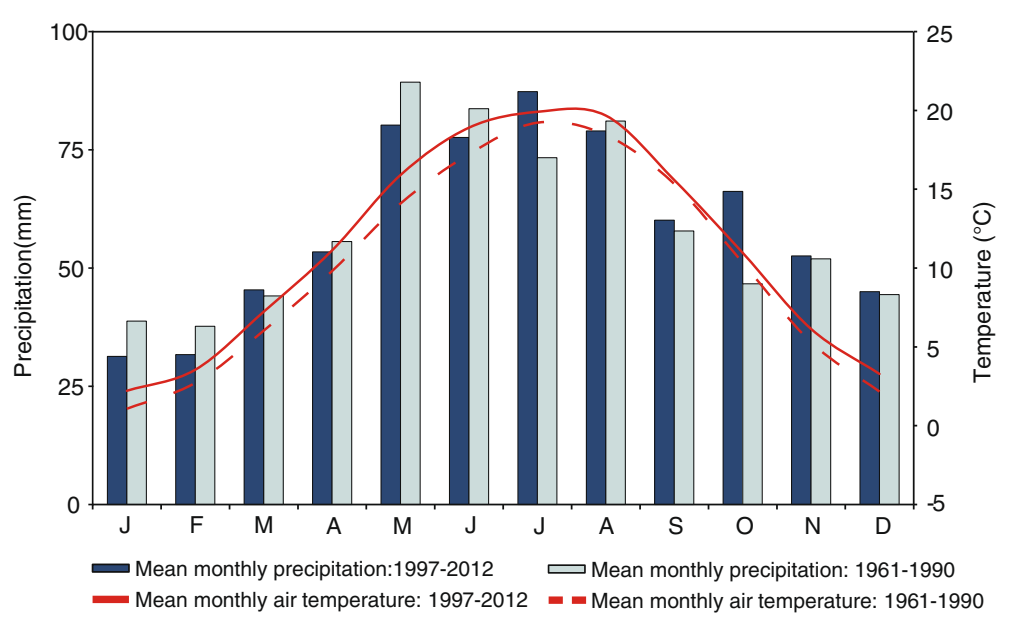

Fig. 1 Climate data for Breisach research plot for the 1961 to 1990 Climate Normals and the growing period 1997-2012 
Table 1 Research plot soil types and nutrient composition

\begin{tabular}{|c|c|c|c|c|c|c|c|}
\hline Depth $(\mathrm{cm})$ & Soil type & $\mathrm{pH}$ & Organic matter (\%) & $N(g / k g)$ & $P(\mathrm{mg} / \mathrm{kg})$ & $\mathrm{K}(\mathrm{mg} / \mathrm{kg})$ & $\mathrm{Mg}(\mathrm{mg} / \mathrm{kg})$ \\
\hline $0-30$ & Silty loam ${ }^{a}$ & 7.7 & 3.7 & 2.6 & 17.6 & 107.9 & 120.0 \\
\hline $30-60$ & Sandy clay silt & 7.8 & 2.1 & 1.3 & 8.8 & 33.2 & 110.0 \\
\hline $60-90$ & Sandy silt & 7.8 & 1.8 & 1.0 & 4.4 & 24.9 & 110.0 \\
\hline
\end{tabular}

aformerly ploughed

design. The initial aim of the research plot was to investigate the growth of different tree species within a widely spaced planting design. Beside wild cherry, other broadleaf species such as European ash (Fraxinus excelsior L.), pedunculate oak (Q. robur L.), sycamore (Acer pseudoplatanus L.), small-leaved lime (Tilia cordata Mill.) and European hornbeam are grown in the mixture. The initial spacing of all trees on the research plot was $1.5 \mathrm{~m} \times$ $7.5 \mathrm{~m}$ and $1.5 \mathrm{~m} \times 15.0 \mathrm{~m}$. Trees were sampled during regular thinning treatments at the end of the $2012(n=$ $20)$ and $2013(n=19)$ growing seasons, the total number of sampled trees $(n=39)$ is in the range of that suggested by Roxburgh et al. (2015). Since the trees were felled during the period of winter dormancy, biomass refers to leafless above ground biomass. The sample trees are representative of all social classes (Kraft 1884) ranging from dominant and co-dominant individuals to dominated and suppressed individuals. The dominated and suppressed trees were additionally sampled to augment the allometric curve at the lower end, as is common practice to cover the entire spread of tree sizes on the plot (Cifuentes Jara et al. 2015). Up to the point of sampling no management operations such as thinning or pruning were applied to the sampled trees.

After measuring stem diameter at breast height $\left(d_{1.3 \mathrm{~m}}\right)$ with a diameter tape providing an accuracy of $\pm 1 \mathrm{~mm}$ the sample trees were felled below a height of $0.1 \mathrm{~m}$. and tree length was measured with a measuring tape (accuracy $\pm 1 \mathrm{~mm}$ ). It should be noted that length instead of height was measured. This signifies a more accurate measurement post felling in contrast to height measured on a standing tree. The large spread of $d_{1.3 \mathrm{~m}}$ shown in Table 2 represents the entire spectrum of trees available on the research site. Post felling, the trees were debranched. Branches were cut into segments, with the cuts being located where the diameter increased in $1.0 \mathrm{~cm}$ intervals. i.e., a branch was cut where it had an exact diameter of $1.0 \mathrm{~cm}, 2.0 \mathrm{~cm}, 3.0 \mathrm{~cm}, \ldots$ each forming a distinct diameter class $(D C)$. These diameter

Table 2 Sample overview

\begin{tabular}{|c|c|c|c|c|c|c|c|}
\hline \multirow[t]{2}{*}{ Year } & \multirow[t]{2}{*}{$n$} & \multicolumn{3}{|c|}{$d_{1.3 \mathrm{~m}}(\mathrm{~cm})$} & \multicolumn{3}{|c|}{ Tree length (m) } \\
\hline & & $\min$ & mean & $\max$ & $\min$ & mean & $\max$ \\
\hline 2012 & 20 & 2.2 & 9.9 & 20.7 & 3.4 & 8.5 & 12.3 \\
\hline 2013 & 19 & 3.4 & 11.8 & 25.6 & 4.6 & 10.2 & 14.6 \\
\hline
\end{tabular}

measurements as well as all diameter measurements excluding the $d_{1.3 \mathrm{~m}}$ were performed using a calliper (accuracy $\pm 1 \mathrm{~mm}$ ). The fresh weights were determined for all $D C$ s within both stem and branch fractions (see Fig. 2). Stem biomass was weighed (All weights were measured using a Mettler PM 4600 Delta Range scale with an accuracy of $\pm 0.01 \mathrm{~g}$ below $600.00 \mathrm{~g}$ and $\pm 0.1 \mathrm{~g}$ above $600.00 \mathrm{~g}$ to a maximum of $4100.0 \mathrm{~g}$ ) and additional diameter measurements were used to calculate the stem biomass in the same way as branches. Sample discs and branch samples from each $D C$ were taken for the construction of a fresh/dry- weight conversion factor.

To analyse the wood/bark- proportion of the different $D C$, bark thickness was measured in four radii at every ascending metre $(n=175)$ for the 20 trees sampled in 2012, these data were used to calculate a regression line between stem diameter and double bark thickness (Pryor 1988; Dagnelie et al. 1999; Toader 2009). Furthermore, the samples taken for the fresh/dry- weight conversion factor were debarked and both compartments (wood and bark), were separately weighed (using the scale described above). These samples $(n=99)$ were also obtained from the 20 sample trees from 2012 intended to separately attain biomass data for wood and bark. After taking the fresh weight, all stem discs and branch samples including wood and bark were oven-dried at $105^{\circ} \mathrm{C}$ until reaching a constant weight.

Analysis for the determination of carbon (C), nitrogen $(\mathrm{N})$, phosphorus $(\mathrm{P})$, potassium $(\mathrm{K})$, magnesium $(\mathrm{Mg})$ and calcium (Ca) content was carried out according to standardised procedure (VDLUFA 1976, 2011). Wood and bark analyses were based on homogenised samples taken from three sampled trees. Bark was removed from the sample pieces prior to analysis. Wood and bark was analysed separately. All samples used for the nutrient analyses were air-dried to avoid the excessive loss of volatile compounds which may occur under forced drying conditions. The results presented reflect a mean of these values. In order to quantify the biomass production of single branches, the branch diameter at origin $\left(b d_{\text {origin }}\right)$ and the fresh biomass was recorded for branches with a diameter of approximately $3 \mathrm{~cm}$ upwards $(3 \mathrm{~cm}$ represents the diameter at which a branch would be pruned (Springmann et al. 2011)). Data were sourced in 2012 ( $n$ $=200)$ and in $2013(n=130)$. For the calculation of dry biomass, the same method was used as described above. 


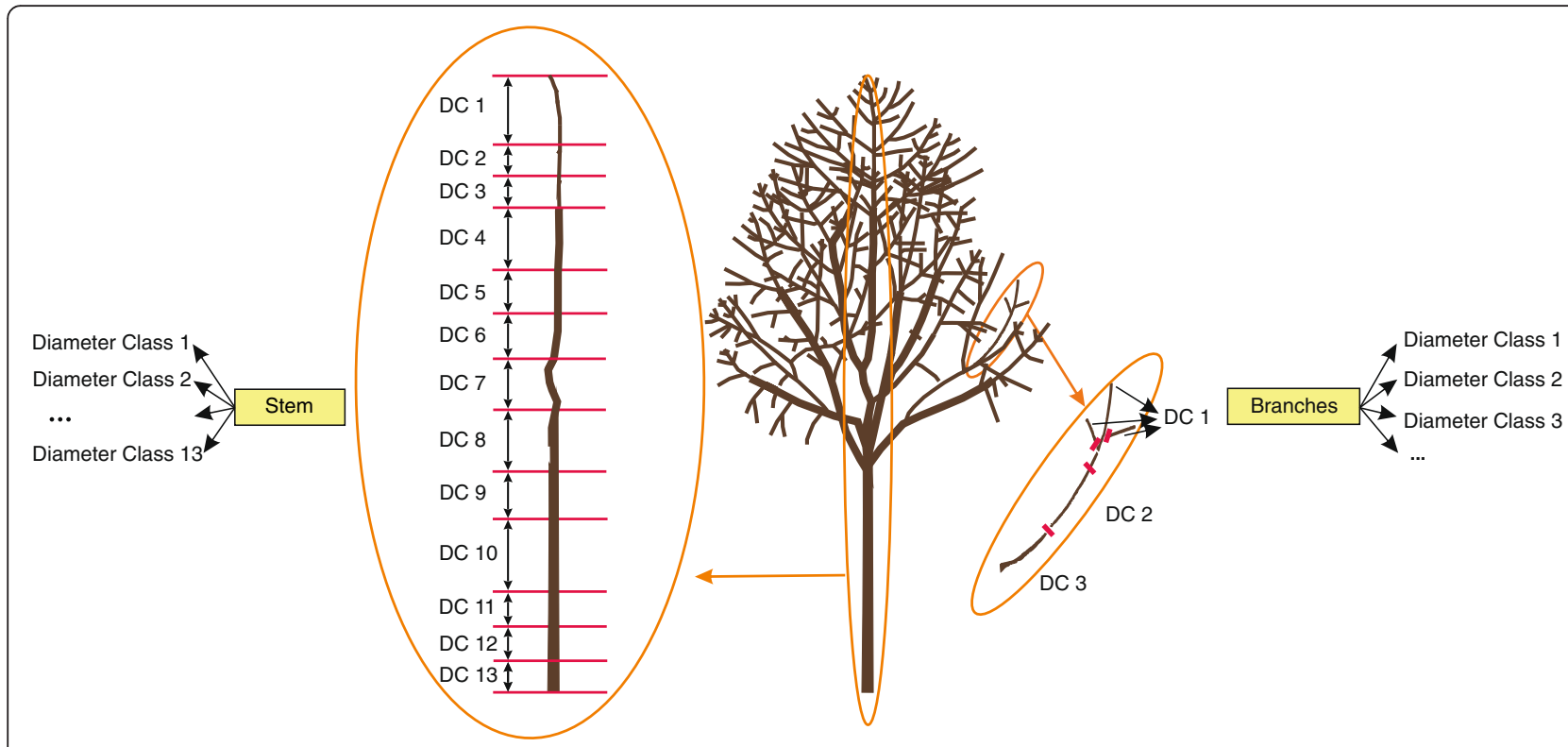

Fig. 2 Sampling methodology showing the distribution of stem and branches into diameter classes (DC)

\section{Data analysis}

All data exploration and analysis were carried out using the $\mathrm{R}$ programming environment 3.2.3 ( $\mathrm{R}$ Core Team 2015). The level of significance was assumed to be $p=$ 0.05 for all analyses. Where appropriate, normality was tested with a Shapiro-Wilk test. It is common practice to use allometric biomass equations as a cost effective and efficient method of relating an easily measurable parameter to that of a less obtainable dependent factor such as dry tree weight, or total bark weight (Parresol 1999; Zianis et al. 2005; Picard et al. 2012; Morhart et al. 2013; Roxburgh et al. 2015; Cifuentes Jara et al. 2015). The biomass models used within this study follow the form given in Eq. 1, where $Y$ is the dependent variable (biomass), $X$ the independent predictor variable, and $a$ and $b$ are the regression coefficients. Both height and $d_{1.3 \mathrm{~m}}$ are frequently used as predictor variables (Zianis et al. 2005; Picard et al. 2012), both known to be strongly indicative of dry above ground biomass.

$$
Y=a X^{b}+\in
$$

The independent predictor variables plus the dry weight data for the whole tree (exclusive of roots, stump and leaves), stem, branch and bark compartments were natural log transformed. This is common practice within biomass estimation procedures to allow for full statistical scrutiny of the data (Sprugel 1983). The log transformation of data on both $x$ and $y$ axis renders a linear relationship thus denoting the correct fitment of an allometric power model (Picard et al. 2012; Morhart et al. 2013) and also corrects data for heteroscedasticity
(Zeng and Tang 2011; Roxburgh et al. 2015), which is typical for biomass data (Parrasol 1999). The R package: systemfit was used for the regression analysis (Henningsen and Hamann 2007) seemingly unrelated regression (SUR) analysis was applied to ensure the additivity of the calculated biomass equations (Parresol 1999, 2001). Regression was carried out utilising the log transformed data. Residuals were assessed for homoscedasticity by visual analysis of the studentised residuals against predicted values, meanwhile, a normal distribution was assessed utilising normal Q-Q plots. A Durbin-Watson test was carried out to assess whether there was autocorrelation between residuals and the resultant Variance Inflation Factor (VIF) evaluated in order to assess for multicolliniarity between variables. The use of natural log transformed data presents a tendency to produce a negative bias (Baskerville 1972; Sprugel 1983; Zeng and Tang 2011). Utilising the standard error of the estimate $(\mathrm{Se})$, a bias correction factor $(C F)$ was applied (Eq. 2) as proposed by Baskerville (1972). Values for Se and CF can be seen in Table 4. Retransformation to arithmetic form was carried out using the regression coefficients deduced from the general linear function (see Eq. 3).

$$
\begin{aligned}
& C F=\exp \left(\frac{S e^{2}}{2}\right) \\
& \hat{Y}=\exp \left(a_{0}+b_{0} \ln x\right) C F \quad X \in
\end{aligned}
$$

The regression line for double bark thickness was calculated using standard linear regression methods following the form of Eq. 4. 


$$
Y=a+b X+\epsilon
$$

\section{Results and discussion Tree biomass}

Total tree biomass ranged from $0.84 \mathrm{~kg}$ up to a maximum of $256.04 \mathrm{~kg}$. Results were recorded for stem and branch fractions. Table 3 shows the results for calculated dry biomass per $D C$ for stem and branch portions for all trees separated by $d_{1.3 \mathrm{~m}}$ classes with $1 \mathrm{~cm}$ intervals. All values represent average values derived from sample trees. Trees with a $d_{1.3 \mathrm{~m}}$ of less than $2.2 \mathrm{~cm}$ are not present within the sample, hence are unrepresented within the results. Trees with a larger $d_{1.3 \mathrm{~m}}$ naturally possess a greater number of diameter classes in both stem and branch fractions. $26 \mathrm{DCs}$ were defined for the stem fraction and twelve for the branch fraction across all sampled trees. Trees with a larger $d_{1.3 \mathrm{~m}}$ possessed a greater branch biomass with the greatest proportion held within the smallest $D C$. The production of stem sections with an overbark diameter greater than $7 \mathrm{~cm}$ representing the merchantable timber volume starts when trees have reached a $d_{1.3 \mathrm{~m}}$ of approximately $4 \mathrm{~cm}$. Thereafter, an increasing $d_{1.3 \mathrm{~m}}$ also increases this proportion.

\section{Bark of wild cherry}

Beside information on biomass distribution between $D C$ within the tree we also collected data providing information towards the percentage of bark biomass in relation to measured sectional overbark diameter (Fig. 3). Bark percentage reduces with increasing tree diameter. This is both logical and in accordance with other authors such as Hamilton (1975) who discusses various broadleaved species. The smallest classes possess the highest proportion of bark, reaching maximum values of over $70 \%$ of total dry biomass in stem sections at diameters of up to $1 \mathrm{~cm}$. Bark proportion rapidly decreases with an increasing diameter reaching a more constant proportion of $20 \%$ decreasing to $10 \%$ above diameters of approximately $8 \mathrm{~cm}$. The percentage of bark per diametric class has previously been presented, showing comparable trends for short rotation hybrid poplar crops (Guidi et al. 2008; Morhart et al. 2013). Within such systems bark content is especially important in regards to nutrient export. Model 9 was constructed in order to facilitate the calculation of bark percentage for any given sectional diameter $\left(d_{\text {overbark }}\right)$. The quantification of bark biomass for wild cherry can aid the calculation of nutrient removal from the system when considering harvesting export scenarios and varying silvicultural treatments.

In order to model the thickness of bark, measurements were taken at $1 \mathrm{~m}$ intervals at all heights on the stem for 20 trees (2012) as described previously. Double bark thickness was found to range from $2 \mathrm{~mm}$ for sectional diameters of $1 \mathrm{~cm}$ up to $8 \mathrm{~mm}$ for diameters of $20 \mathrm{~cm}$ (Fig. 4). According to van Laar and Akça (1997) who propose that a linear relationship is exhibited between stem diameter and bark thickness, we derived a linear model (model 10) that is comparable to other studies. Our empirical findings showed that bark thickness is closely related to the diameter of the tree at the point of measurement concurring with Hamilton (1975). The data collected within this study are framed by that published by Pryor (1988) and Dagnelie et al. (1999). The model proposed by Toader (2009) also correlated well within the diameter range studied. Pryor (1988), undertook a similar sampling design to that presented in this study (i.e., within all $D C$ s and at all heights on the stem, representing multiple measurements per tree), but measured trees with $d_{1.3 \mathrm{~m}}$ of up to $50 \mathrm{~cm}$. Dagnelie et al. (1999) used stem circumference as a predictor variable, while Toader (2009) used $d_{1.3 \mathrm{~m}}$, both took single bark thickness measurements at $1.3 \mathrm{~m}$ above the ground, representing one single measurement per tree. As the bark of wild cherry is thin when young, becoming more ridged with age (Pryor 1988), the juvenile status of our sampled trees represents a sample set which has a potential bias towards thinner bark. Nevertheless, the number of observations within a relatively narrow $d_{1.3 \mathrm{~m}}$ range allow for accurate estimations which can be used for further calculations such as underbark volume calculations and other single tree calculations or stand level estimations (van Laar and Akça 1997).

\section{Modelling the biomass of widely spaced wild cherry}

Based on the presented empirical measurements, allometric biomass models (Fig. 5 and Table 4) were constructed using the defined predictor variables $\left(d_{1.3 \mathrm{~m}}\right.$, $b d_{\text {origin }}$ and overbark stem/branch diameter $\left.\left(d_{\text {overbark }}\right)\right)$, each displaying a high predictive significance. It should be noted that length as disregarded as a predictor variable due to high multicollinearity (assessed using calculated VIF per model). The absence of length or height facilitates the application of the model since the accurate measurement of tree height in the field can be time consuming for a large number of standing trees.

The visualisation of the whole tree regression model (Fig. 5) clearly shows the good fit of the allometric model, spread of points across the range of diameter measurements and between the two sample years. Included in Table 4 are the parameters for the biomass equations for total tree, stem and branch. All parameter estimates were found to have a $p$-value of less than 0.001 providing high significance. The displayed $r_{\text {adj }}^{2}$ of more than 0.96, in combination with low values for the normalised root mean square error (NRMSE) show an exceptionally high model fit. As 
Table 3 Calculated dry weights $(\mathrm{kg})$ for stem and branch sections by diameter class (DC)

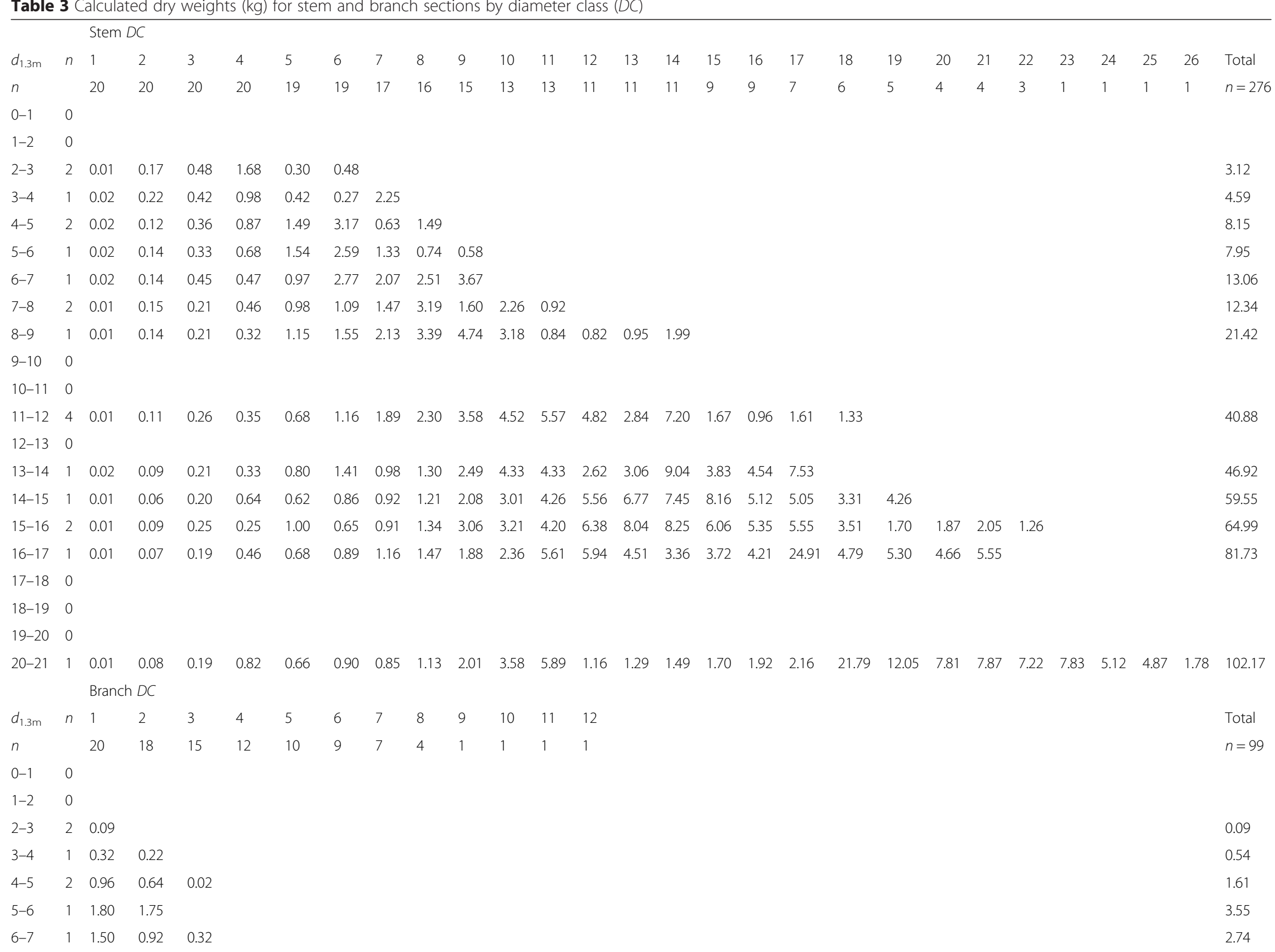


Table 3 Calculated dry weights $(\mathrm{kg})$ for stem and branch sections by diameter class (DC) (Continued)

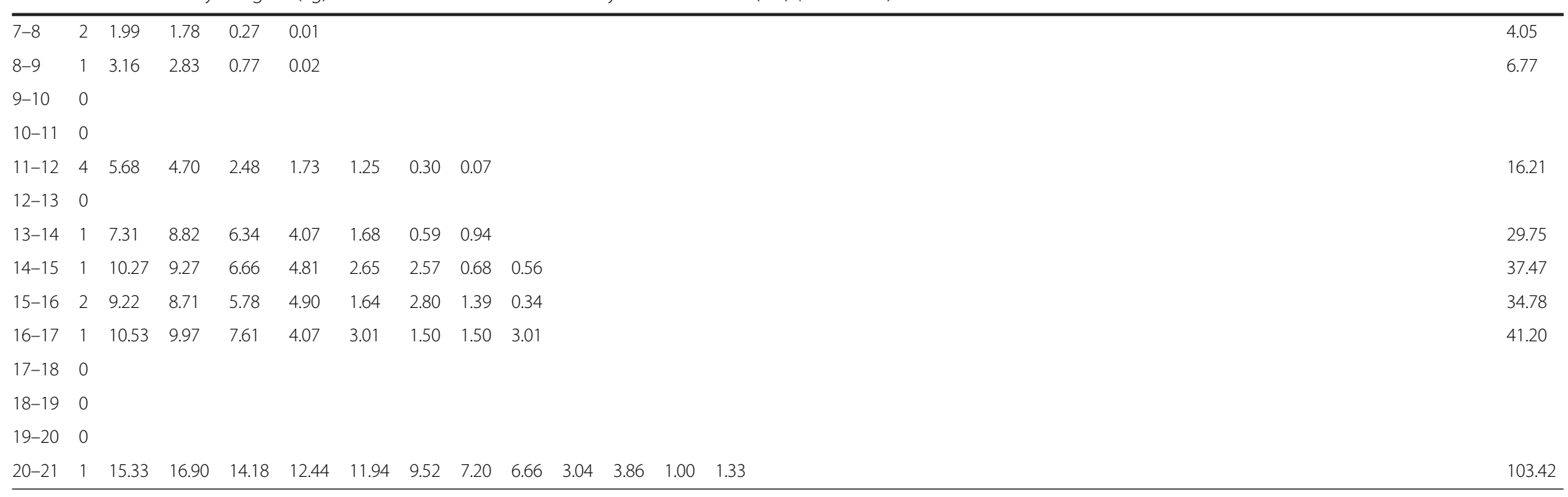




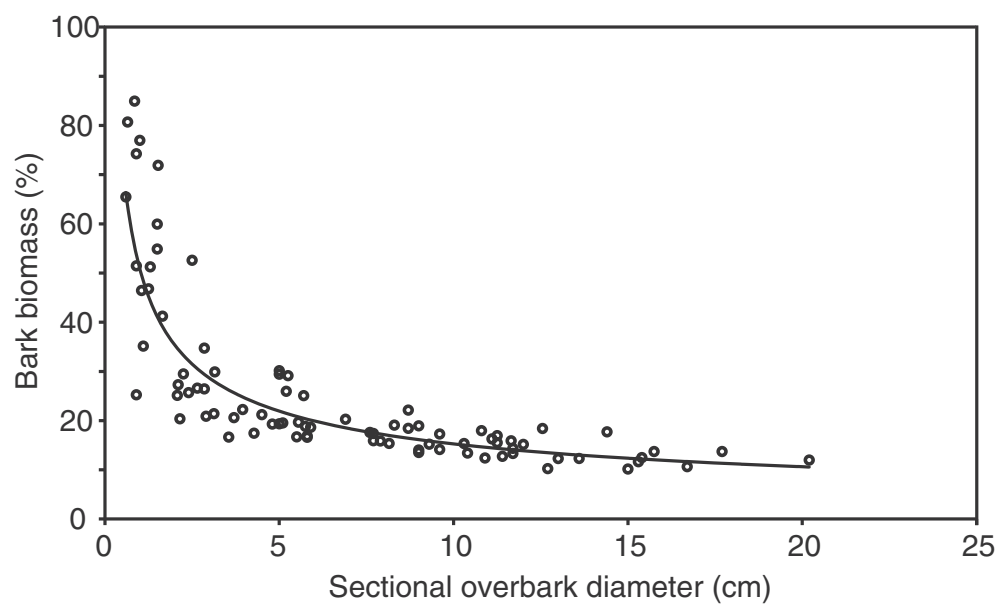

Fig. 3 Percentage dry bark biomass as a function of sectional overbark diameter

$d_{1.3 \mathrm{~m}}$ of the sample trees increased, the number of observations decreased, thus providing a subsequent decrease in predictive precision. An increase in variance on a logarithmic scale with increasing diameter can be attributed to the deviation of residuals around the line of best fit (Roxburgh et al. 2015). Working also with juvenile wild cherries $(n=18)$ with a maximum age of 23 years Alberti et al. (2006) published one allometric equation (following the form of Eq. 1; coefficients: $a=0.12, b=2.33$ ) for whole tree biomass based on data from Italy. In comparison, such results show corresponding biomass values for small $d_{1.3 \mathrm{~m}}$ but suggest an increasing divergence with increasing $d_{1.3 \mathrm{~m}}$. The work by Alberti et al. (2006) represents the only previous biomass equation for wild cherry, other published equations have been constructed for the estimation of volume. Dagnelie et al.
(1999) sampled 334 trees in Belgium with an age of 15 to 80 years in order to predict stem volume. Their resulting model utilised circumference at different heights and total tree height as predictor variables in the form of a polynomial function. Furthermore, in recent research Hackenberg et al. (2014) utilised terrestrial laser scanning methodology for the analysis and prediction of total volume and merchantable timber volume (diameter over $7 \mathrm{~cm}$ ) of wild cherry on the same study site, allometric models were constructed as a method of ground truthing the point cloud data. Individual branch models (Models 4 and 8) using the $b d_{\text {origin }}$ as a predictor variable reveal that branches with a diameter of $3 \mathrm{~cm}$ present a total dry biomass of $0.7 \mathrm{~kg}$ (including $0.2 \mathrm{~kg}$ of dry bark biomass), likewise, branches with a diameter of $10 \mathrm{~cm}$ can be suggested to contain $21.4 \mathrm{~kg}$ of dry biomass (4.7 kg dry bark).

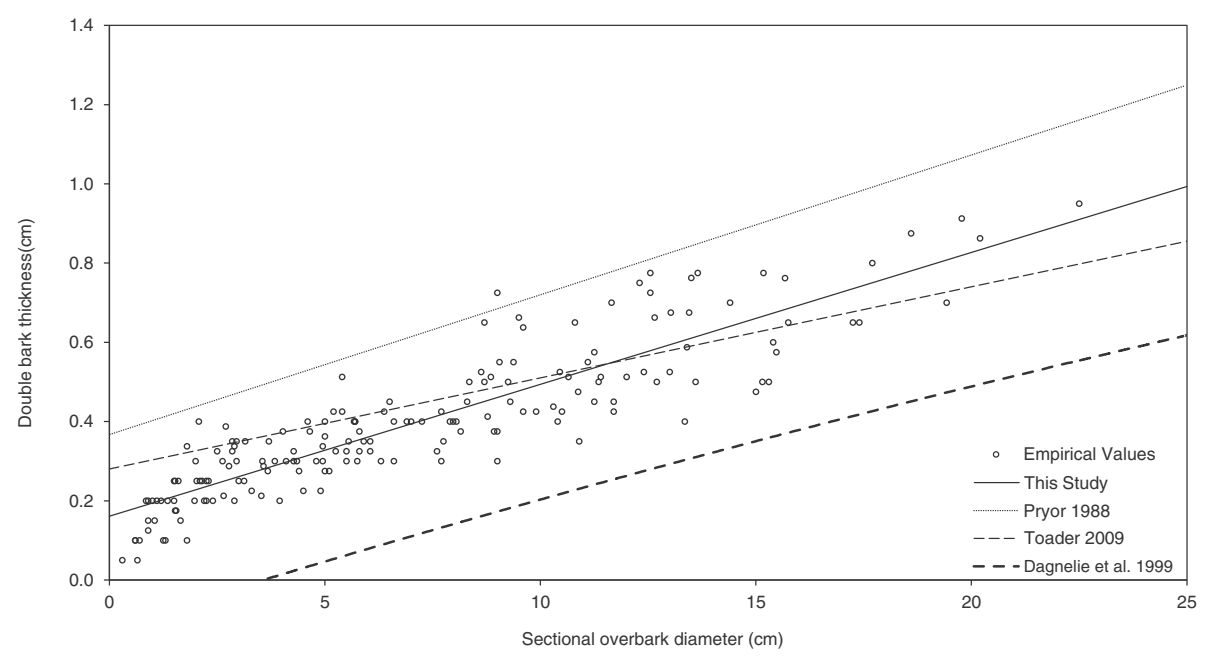

Fig. 4 Double bark thickness as a function of sectional overbark diameter 

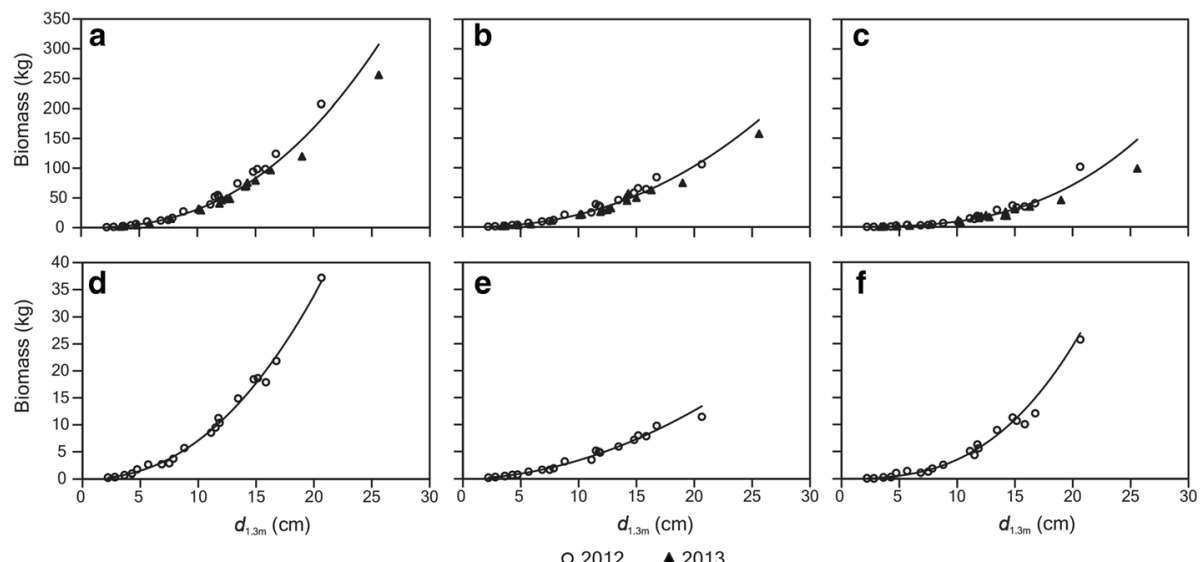

Fig. 5 Biomass models for (a) whole tree dry biomass, (b) stem dry biomass, (c) branch dry biomass, (d) whole tree dry bark biomass, (e) stem dry bark biomass, (f) branch dry bark biomass, utilising $d_{1.3 \mathrm{~m}}$ as predictor variable. Model parameters can be seen in Table 4

We consider that the ten biomass models introduced in Table 4 create a solid foundation for future modelling activities where the biomass and yield of wild cherry needs to be quantified. The presented models are both site and age specific, predictions gained through the application of these models should be treated cautiously when applied to other stand conditions.

Based on the detailed results of biomass per $D C$ (Table 3) and the related bark proportion by sectional diameter (see also Fig. 3) the share of bark and wood can be determined. Using the models given in Table 4 we are able to precisely determine the proportion of bark and wood tissues within specified $D C$ and at a whole tree level, between different tree compartments. Whole tree predictions can be made per $d_{1.3 \mathrm{~m}}$ class to demonstrate the change in biomass distribution between tree parts with increasing diameter. The presented models can be used as a basis for further biomass and nutrient assessments on a single tree basis as well as at the plot scale. With the exception of models 4 and 8-10, all presented models are based on $d_{1.3 \mathrm{~m}}$ as independent predictor variable, as such a variable that is quick and easy to measure in the field. Models 4 and 8 was constructed in order to estimate the amount of biomass and nutrients that are removed by pruning operations and is therefore based on the $b d_{\text {origin }}$ a measurement that can be derived from pruned branches on the ground derived during normal pruning treatments. The presented models utilise trees of a similar age $( \pm 1$ year) but of varied size (diameter and height), assumptions should not overlook the reasons for differences in tree size. Such differences observed within this study may amount to differences in competition (both inter- and intraspecific), plant quality (genetics) and variation in microsite conditions.

Table 4 Model parameters derived from regression analysis and statistical parameters

\begin{tabular}{|c|c|c|c|c|c|c|c|c|c|c|c|}
\hline \multirow[t]{2}{*}{ Output } & \multirow[t]{2}{*}{ Model } & \multirow{2}{*}{$\begin{array}{l}\text { Independent } \\
\text { variable }\end{array}$} & \multirow{2}{*}{$\begin{array}{l}\text { Number of } \\
\text { observations }\end{array}$} & \multicolumn{4}{|c|}{ Parameter estimates } & \multicolumn{3}{|c|}{ Fit statistics } & \multirow{2}{*}{$\begin{array}{l}\text { Correction } \\
\text { factor (CF) }\end{array}$} \\
\hline & & & & $a_{0}$ & $\exp \left(a_{0}\right)$ & $b_{0}$ & $p$ & $r_{\mathrm{adj}}^{2}$ & $\mathrm{Se}$ & NRMSE & \\
\hline Whole tree biomass & 1 & $d_{1.3 m^{a}}$ & 39 & -2.216 & 0.109 & 2.450 & $<0.001$ & 0.991 & 0.138 & 0.025 & 1.010 \\
\hline Stem biomass & 2 & $d_{1.3 \mathrm{~m}}{ }^{\mathrm{a}}$ & 39 & -2.228 & 0.108 & 2.290 & $<0.001$ & 0.988 & 0.146 & 0.027 & 1.011 \\
\hline Branch biomass & 3 & $d_{1.3 \mathrm{~m}}{ }^{\mathrm{a}}$ & 39 & -4.625 & 0.010 & 2.965 & $<0.001$ & 0.969 & 0.316 & 0.098 & 1.051 \\
\hline Individual branch biomass & 4 & $b d_{\text {origin }}$ & 370 & -3.540 & 0.029 & 2.868 & $<0.001$ & 0.959 & 0.470 & 0.047 & 1.117 \\
\hline Total bark biomass & 5 & $d_{1.3 \mathrm{~m}}{ }^{\mathrm{a}}$ & 20 & -3.244 & 0.039 & 2.258 & $<0.001$ & 0.991 & 0.137 & 0.015 & 1.009 \\
\hline Stem bark biomass & 6 & $d_{1.3 \mathrm{~m}}{ }^{\mathrm{a}}$ & 20 & -3.165 & 0.042 & 1.900 & $<0.001$ & 0.992 & 0.105 & 0.037 & 1.006 \\
\hline Branch bark biomass & 7 & $d_{1.3 \mathrm{~m}}{ }^{\mathrm{a}}$ & 20 & -5.321 & 0.005 & 2.848 & $<0.001$ & 0.958 & 0.377 & 0.024 & 1.080 \\
\hline Individual branch bark biomass & 8 & $b d_{\text {origin }}$ & 69 & -4.560 & 0.010 & 2.669 & $<0.001$ & 0.975 & 0.304 & 0.102 & 1.047 \\
\hline Bark percentage by sectional diameter & 9 & $d_{\text {overbark }}$ & 85 & 3.928 & 50.805 & -0.522 & $<0.001$ & 0.807 & 0.233 & 0.003 & 1.028 \\
\hline Bark thickness by diameter class & $10^{\mathrm{b}}$ & $d_{\text {overbark }}$ & 174 & - & 0.033 & 0.161 & $<0.001$ & 0.797 & 0.084 & 0.672 & - \\
\hline
\end{tabular}

a Length was excluded as a predictor variable as the VIF value was greater than 10 (10.737) indicating a high degree of multicollinearity

${ }^{\mathrm{b}}$ Standard linear model (see Eq. 4) 
To counter inherent additivity problems when applying biomass equations (Parresol 2001) we utilised a SUR fitting technique for defined tree components (stem, branch and bark). The proportion of bark and wood tissues divided between stem and branch fractions can be seen in Fig. 6 for trees with a $d_{1.3 \mathrm{~m}}$ between 1 and $25 \mathrm{~cm}$ including percentages as well as absolute values. It was observed that with increasing $d_{1.3 \mathrm{~m}}$ the proportion of branch biomass increased. Branch proportion rises from $10 \%$ at the smallest $d_{1.3 \mathrm{~m}}$ to $40 \%$ in trees with $d_{1.3 \mathrm{~m}}$ of $25 \mathrm{~cm}$. Since the sample trees were unpruned, it can be suggested that under such conditions the branch proportion will continue to rise until self-pruning takes place at a time when there is sufficient canopy closure. However, it must be noted that wild cherry is a tree species that does not self-prune well (Pryor 1988); therefore, dead branches remain attached to the stem. Bark proportion within the stem fraction reduces as the $d_{1.3 \mathrm{~m}}$ increases. Tree boles with a greater amount of stem wood above $10 \mathrm{~cm}$ in diameter will have a lower bark proportion. Results shown in Table 3 demonstrate that trees with a $d_{1.3 \mathrm{~m}}$ of $8 \mathrm{~cm}$ already produce overbark stem diameters of above $10 \mathrm{~cm}$, as the proportion of small wood (diameter below $7 \mathrm{~cm}$ ) decreases; the share of bark also decreases. Likewise, branch bark proportion also remains relatively constant above this stem diameter, here, a balance is found between the production of new branches with low diameter and high bark proportion offset by the thickening and a relative reduction in bark proportion in larger branches.

\section{Carbon and nutrient content}

Analysis has confirmed that carbon constitutes approximately $50 \%$ (47.8 \%) of woody biomass tissues (Table 5), a value that is consistent with current literature (Alriksson and Eriksson 1998; Pretzsch 2010). Analyses also showed that carbon held a greater proportion within bark tissues than within wood, marginally more in branch bark than in stem bark (51.3\% vs. $50.4 \%$ ). Nutrient concentrations of above ground woody biomass were found in the order of: $\mathrm{C}>\mathrm{N}>\mathrm{Ca}>\mathrm{K}>\mathrm{Mg}>\mathrm{P}$ concurring with results presented by Wang et al. (1996). The woody parts of branches display a greater nutrient content than analysed stem sections while branch bark was found to contain a lesser amount of nutrients than the stem bark. Nevertheless, it was observed, that the total branch biomass contains higher percentages of nutrients than that found within the stem fraction, a fact that can be attributed to greater bark proportion due to smaller cross sectional area. Other studies have also shown higher nutrient concentrations in the same way (Wang et al. 1996; Alriksson and Eriksson 1998; Uri et al. 2002; Uri et al. 2007). Bark tissues also hold greater amounts of $\mathrm{C}, \mathrm{N}, \mathrm{P}, \mathrm{K}, \mathrm{Mg}$ and $\mathrm{Ca}$ than wood tissues, which are relatively nutrient poor. As sectional diameter decreases there is proportionally more nutrient contained on average within these tissues.

Figure 7 demonstrates the proportional carbon and nutrient content between tree compartments namely stem subdivided into wood and bark, and branches composed of wood and bark. Carbon allocation within the studied wild cherry follows the order of stem wood >

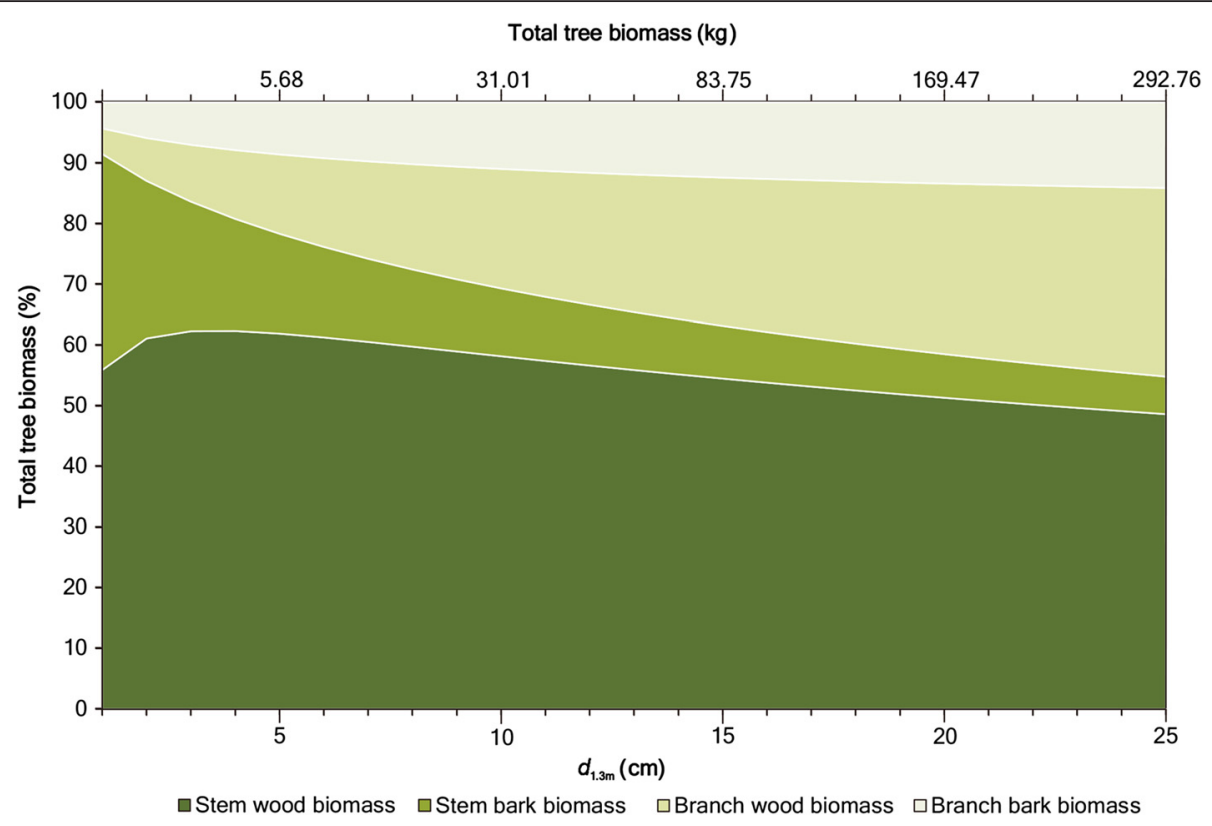

Fig. 6 Percentages of total tree biomass between tree compartments 
Table 5 Carbon and nutrient content within different tree compartments

\begin{tabular}{|c|c|c|c|c|c|c|}
\hline & C (\% Dry Mass) & $\mathrm{N}(\mathrm{mg} / \mathrm{g})$ & $P(\mathrm{mg} / \mathrm{g})$ & $\mathrm{K}(\mathrm{mg} / \mathrm{g})$ & $\mathrm{Mg}(\mathrm{mg} / \mathrm{g})$ & $\mathrm{Ca}(\mathrm{mg} / \mathrm{g})$ \\
\hline Wood from branches & 47.80 & 1.47 & 0.26 & 1.08 & 0.34 & 2.58 \\
\hline Bark from branches & 51.34 & 5.18 & 0.62 & 2.87 & 0.46 & 18.10 \\
\hline Wood from stem & 47.80 & 1.03 & 0.18 & 0.94 & 0.24 & 1.27 \\
\hline Bark from stem & 50.35 & 6.24 & 0.74 & 3.18 & 0.57 & 20.94 \\
\hline
\end{tabular}

branch wood $>$ branch bark $>$ stem bark becoming increasingly distinct at larger $d_{1.3 \mathrm{~m}}$ (at $d_{1.3 \mathrm{~m}}<4 \mathrm{~cm}$ carbon displays greater stem bark proportions than total branch) the same distribution of carbon between tree parts is demonstrated by Wang et al. (1996) and Singh and Lodhiyal (2009).

On a general level, larger proportions of nutrients are contained within the bark of smaller trees. Nutrient content becomes proportionally more constant with increased $d_{1.3 \mathrm{~m}}$ while the nutrient content held within the branch fraction increases. Growth of a plant is generally proportional to the amount of available nitrogen (Wang et al. 2000). The largest proportion of nitrogen, a nutrient which is essential for photosynthesis, rapid growth and biomass production is stored within stem bark tissues in early developmental stages. Alongside an increased $d_{1.3 \mathrm{~m}}$ the share of nitrogen stored in branch bark increases, leading to a share of around $35 \%$ at a $d_{1.3 \mathrm{~m}}$ of $25 \mathrm{~cm}$, a value that is only slightly less than the $40 \%$ contributed by stem wood and stem bark together. Phosphorus, used within energy transfer processes remains in small concentrations within whole tree biomass (remaining below $0.5 \%$ of total tree biomass at all analysed diameters). Nevertheless, a clear trend towards an increase of the share of the branch bark can be observed. It should be noted that soil $\mathrm{pH}$ is higher than that suggested for optimal phosphorus solubility and therefore availability to the plant is reduced. The final of the three major nutrients, potassium, shows a comparable distribution within the tree fractions to phosphorus although at four times the magnitude. Magnesium displays comparable absolute values to that given by phosphorus, however, a greater share of the element is held within the wood tissues. Calcium concentrations in the bark fraction were observed to be up to 16 times greater than that in corresponding wood tissues. For a given $d_{1.3 \mathrm{~m}}$ of

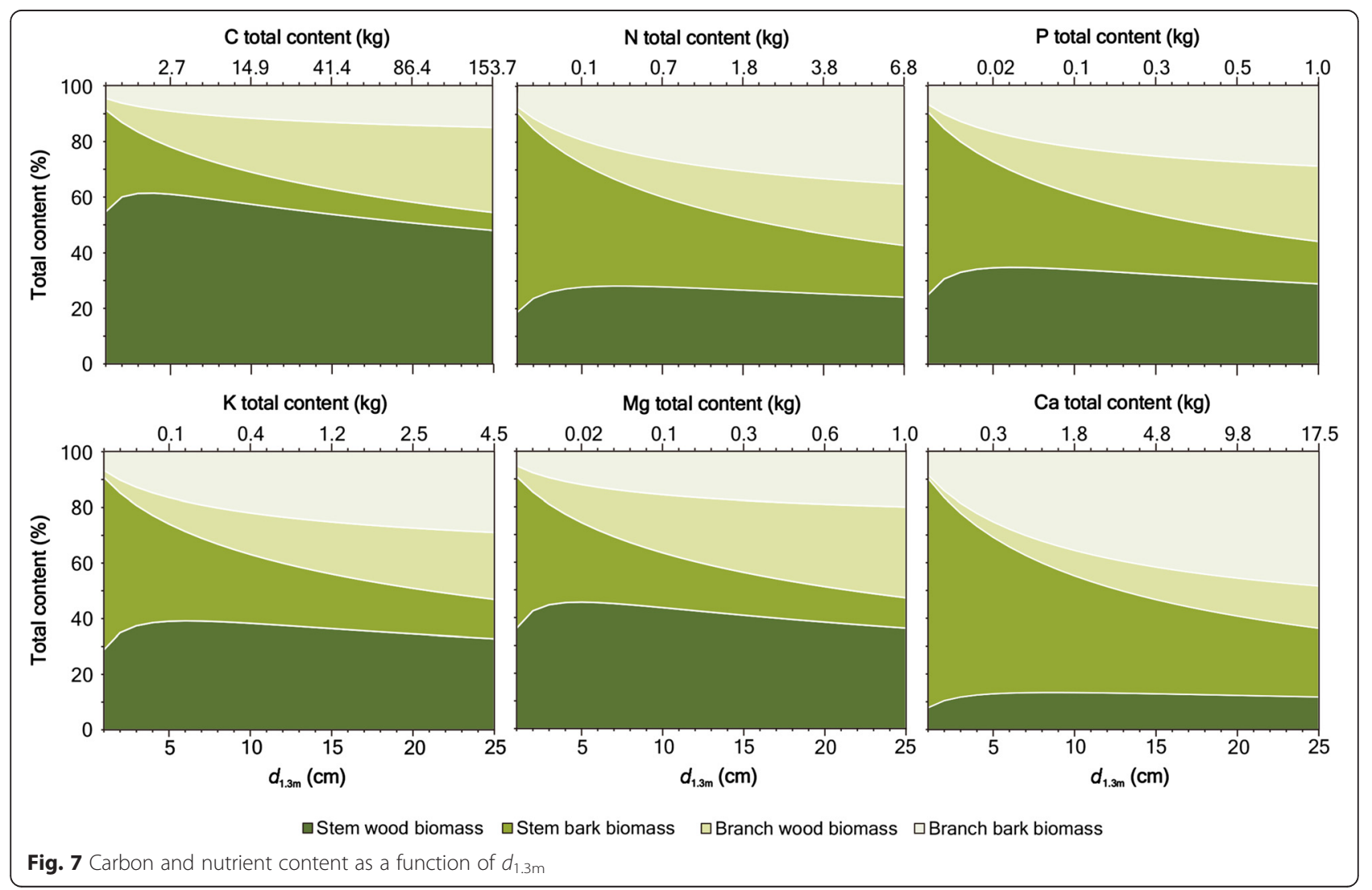


$25 \mathrm{~cm}$ bark tissues including stem and branch fractions contribute approximately $70 \%$ of calcium of the total tree biomass. Calcium has previously been noted to be present in high concentrations within bark tissues due to its function within cell wall lignification processes (André and Ponette 2003), particularly within broadleaved trees (Jacobsen et al. 2003). Calcium is freely available within the soils of this study site and is not limited by external factors.

The allocation of carbon within a tree may vary dependent on species, age, and influencing environmental factors. Wang et al. (2000) showed that at the expense of root growth more carbon was allocated to the leaves/ needles in response to increased shading (Wang et al. 2000). Likewise, a reduction in belowground competition for primary nutrients such as $\mathrm{N}$ and $\mathrm{P}$ may increase the proportion of carbon partitioning above ground (Forrester et al. 2006) thus altering the shoot:root ratio of individual trees. Pretzsch (2010) describes differences in nutrient accumulation between Norway spruce (Picea abies [L.] H. Karst.) and European beech, the former as it senesces, loses accumulated minerals through needle and branch wood, the latter continues to accumulate biomass as it matures, a strategy that may be employed by the broadleaved wild cherry. The nutrient cycling potential of leaf fall is an important aspect to be considered within agroforestry systems. Annual and intra-annual leaf fall may contribute significantly to the soil nutrient status of the site. However, the assessment of leaf biomass as for example carried out by Axelsson et al. (1972), Clough \& Scott (1989) and Alberti et al. (2005) and consequently nutrient cycling through leaf fall is beyond the scope of this paper. Full shade cast by trees within an AFS during the vegetation period may suggest that the use of wild cherry may suit the coproduction of winter crops, further research is needed towards the shade cast potential of such a system.

In order to obtain high quality timber, artificial pruning is a necessary silvicultural procedure (Otter 1954; Balandier and Dupraz 1999; Springmann et al. 2011). The sample trees employed within this study were unpruned in order to quantify the biomass production potential between tree components. Utilising the derived model for individual branch biomass (Model 4) it can be suggested that approximately $41.9 \mathrm{~kg}$ of branch biomass is pruned per tree during one rotation of $60-80$ years (three pruning treatments). This estimation assumes a standard branch diameter of $3 \mathrm{~cm}$, that there are five branches per whorl and at each pruning treatment five whorls are pruned from each tree (in years 10, 15 and 20). This calculation suggests that removed branches, which are often left on-site, may liberate $4.2 \mathrm{~kg}$ of calcium, $1.7 \mathrm{~kg}$ of nitrogen and $1.0 \mathrm{~kg}$, of potassium (Table 5), also $300 \mathrm{~g}$ and $200 \mathrm{~g}$ of phosphorus and magnesium respectively. At the stand level where 50 to 80 mature crop trees per hectare (Balandier and Dupraz 1999) can be cultivated, this therefore constitutes a large potential recycling of nutrient when left on site. It is likely that the application of pruning treatments needed for the production of high value timber would artificially reduce the proportion of branches as well as reducing the overall diameter growth of the stem (Springmann et al. 2011) and overall biomass production as a consequence of increasing wood quality. Conversely, it can be suggested that thinning operations might increase the rate of growth of released trees. Hence, Fig. 6 could be modified to reflect an increased stem wood proportion. Nevertheless, for the long-term, a high value timber goal must be reached, production of a high value $\log$ requires large $d_{1.3 \mathrm{~m}}$ of above $40 \mathrm{~cm}$ (Thies et al. 2009) this undoubtedly benefits the long term on-site carbon storage ultimately followed by long term storage within ex-situ products.

\section{Conclusions}

The presented study details the amount of biomass within different compartments of wild cherry accounting not only stem and branches, but also the wood and bark content of whole trees. It was demonstrated that larger unpruned trees show a higher proportion of branch biomass, but due to increased stem diameter this counteracts the proportional increase in bark biomass within the whole tree. As a result, a reduction of whole tree bark biomass is observed. Using the derived models the carbon and the nutrient content of whole trees can be calculated. The results show that a single tree at an age of 20 years can store a total amount of $85 \mathrm{~kg}$ of carbon within the aboveground biomass portion, an amount that will increase as the tree matures. This strongly supports the idea of the inclusion of wild cherry within AFS as an option for carbon sequestration e.g., in combination with winter crops. Analysed nutrient content supports previous research outlining nutrient concentration between tree parts. For minimised nutrient export, branches and bark fraction should not be removed at the time of thinning or at eventual harvest whenever possible.

\section{Competing interests \\ The authors declare that they have no competing interests.}

\section{Authors' contributions}

CM and JPS provided equal contributions and should both be regarded as first author. Both CM and JPS participated in the experimental design, carried out, and oversaw data collection and its analysis, furthermore, both authors wrote and reviewed the manuscript. JKS participated in the experimental design, carried out and oversaw data collection, and reviewed the manuscript. HS provided guidance and review of the manuscript. All authors read and approved the final manuscript. 


\section{Acknowledgements}

The authors would like to thank, Cristina Prado Rubio, Benjamin Goebel, Greta Ehrhart, Brian Shaw, George Ciubotaru and Nicoleta Cristea for assistance with data collection and processing. The authors would also like to thank Felix Baab for his valuable support. This research was supported by the EU FP7 project StarTree (Grant Agreement Number 311919), the Federal Ministry of Education and Research (BMBF) within the AGROCOP project (support code 033L051B) and the German Federal Ministry of Food and Agriculture (BMEL) within the project Agro-Wertholz (support code 22031112).

\section{Received: 27 August 2015 Accepted: 8 February 2016} Published online: 11 February 2016

\section{References}

Adler A, Verwijst T, Aronsson P (2005) Estimation and relevance of bark proportion in a willow stand. Biomass Bioenerg 29(2):102-113. doi:10.1016/j. biombioe.2005.04.003

Alberti G, Candido P, Peressotti A, Turco S, Piussi P, Zerbi G (2005) Aboveground biomass relationships for mixed ash (Fraxinus excelsior L. and Ulmus glabra Hudson) stands in Eastern Prealps of Friuli Venezia Giulia (Italy). Ann For Sci 62(8):831-836. doi:10.1051/forest:2005089

Alberti G, Marelli A, Piovesana D, Peressotti A, Zerbi G, Gottardo E, Bidese F (2006) Carbon stocks and productivity in forest plantations (Kyoto forests) in Friuli Venezia Giulia (Italy). Forest@ 3(4):488-495. doi:10.3832/efor0414-0030488

Albrecht A, Kandji ST (2003) Carbon sequestration in tropical agroforestry systems. Agric Ecosyst Environ 99(1-3):15-27. doi:10.1016/S01678809(03)00138-5

Alriksson A, Eriksson HM (1998) Variations in mineral nutrient and C distribution in the soil and vegetation compartments of five temperate tree species in NE Sweden. For Ecol Manag 108(3):261-273. doi:10.1016/S03781127(98)00230-8

André F, Jonard M, Ponette Q (2010) Biomass and nutrient content of sessile oak (Quercus petraea (Matt.) Liebl.) and beech (Fagus sylvatica L.) stem and branches in a mixed stand in southern Belgium. Sci Total Environ 408(11): 2285-2294. doi:10.1016/j.scitotenv.2010.02.040

André F, Ponette Q (2003) Comparison of biomass and nutrient content between oak (Quercus petraea) and hornbeam (Carpinus betulus) trees in a coppicewith-standards stand in Chimay (Belgium). Ann For Sci 60(6):489-502. doi:10.1051/forest:2003042

Axelsson B, Gärdefors D, Hytteborn H, Lohm U, Persson T, Tenow O (1972) Estimation of leaf number and leaf biomass of Hazel Corylus avellana by two methods. Oikos 23(2):281-283. doi:10.2307/3543419

Balandier P, Dupraz C (1999) Growth of widely spaced trees. A case study from young agroforestry plantations in France. Agroforest Syst 43(1):151-167. doi:10.1023/A:1026480028915

Baskerville GL (1972) Use of logarithmic regression in the estimation of plant biomass. Can J For Res 2(1):49-53. doi:10.1139/x72-009

Cifuentes Jara M, Henry M, Réjou-Méchain M, Wayson C, Zapata-Cuartas M, Piotto D, Alice Guier F, Castañeda Lombis H, Castellanos López E, Cuenca Lara R, Cueva Rojas K, Del Águila Pasquel J, Duque Montoya Á, Fernández Vega J, Jiménez Galo A, López O, Marklund L, Michel Fuentes J, Milla F, Návar Chaidez J, Ortiz Malavassi E, Pérez J, Ramírez Zea C, Rangel García L, Rubilar Pons R, Saint-André L, Sanquetta C, Scott C, Westfall J (2015) Guidelines for documenting and reporting tree allometric equations. Ann For Sci 72(6):763-768. doi:10.1007/s13595-014-0415-z

Clough BF, Scott K (1989) Allometric relationships for estimating above-ground biomass in six mangrove species. For Ecol Manag 27(2):117-127. doi:10.1016/0378-1127(89)90034-0

Coello J, Desombre V, Becquey J, Gonin P, Ortisset J, Baiges T, Piqué M (2013) Wild cherry (Prunus avium) for high quality timber. In: Government of Catalonia MoALFFaNE, Catalan Forest Ownership Centre (ed) Ecology and silviculture of the main valuable broadleaved species in the Pyrenean area and neighbouring regions, Santa Perpètua de Mogoda, Spain., pp 13-20

Dagnelie P, Palm R, Rondeux J, Thill A (1999) Tables de cubage des arbres et des peuplements forestiers, 2nd edn. Les Presses Agronomiques de Gembloux, Gembloux, Belgique

DWD (Deutscher Wetterdienst) (2015) Web-based Weather Request and Distribution System (WebWerdis). http://www.dwd.de/webwerdis. Accessed 15 February 2013
Ducci F, Cuyper B, Rogatis A, Dufour J, Santi F (2013) Wild Cherry Breeding (Prunus avium L.). In: Pâques LE (ed) Forest Tree Breeding in Europe, vol 25. Springer, Netherlands, pp 463-511

Evans J (1984) Silviculture of broadleaved woodland. Forestry Commission bulletin, vol 62. H.M. Stat. Off, London

Fang JY, Chen AP, Peng CH, Zhao SQ, Ci L (2001) Changes in forest biomass carbon storage in China between 1949 and 1998. Science 292:2320-2322. doi:10.1126/science.1058629

Forrester DI, Bauhus J, Cowie AL (2006) Carbon allocation in a mixed-species plantation of Eucalyptus globulus and Acacia mearnsii. Improving Productivity in Mixed-Species Plantations. For Ecol Manag 233(2-3):275-284. doi:10.1016/j.foreco.2006.05.018

Guidi W, Piccioni E, Ginanni M, Bonari E (2008) Bark content estimation in poplar (Populus deltoides L.) short-rotation coppice in Central Italy. Biomass Bioenerg 32:518-524. doi:10.1016/j.biombioe.2007.11.012

Hackenberg J, Morhart C, Sheppard J, Spiecker H, Disney M (2014) Highly accurate tree models derived from terrestrial laser scan data: a method description. Forests 5(5):1069-1105. doi:10.3390/f5051069

Hamilton GJ (1975) Forest mensuration handbook. Forestry Commission Booklet, Vol 39. Forestry Commission, London

Hemery G, Clark JR, Aldinger E, Claessens H, Malvolti ME, O'Connor E, Raftoyannis Y, Savill PS, Brus R (2010) Growing scattered broadleaved tree species in Europe in a changing climate: a review of risks and opportunities. Forestry 83(1):65-81. doi:10.1093/forestry/cpp034

Henningsen A, Hamann, JD (2007) systemfit: A Package for Estimating Systems of Simultaneous Equations in R. J Stat Softw 23(4). doi:10.18637/jss.v023.i04

IPCC (2014) Climate Change 2014: Synthesis Report. Contribution of Working Groups I, II and III to the Fifth Assessment Report of the Intergovernmental Panel on Climate Change. Core Writing Team, R.K. Pachauri and L.A. Meyer, Geneva, Switzerland

Jacobsen C, Rademacher P, Meesenburg H, Meiwes KJ (2003) Gehalte chemischer Elemente in Baumkompartimenten. Literaturstudie und Datensammlung. Berichte des Forschungszentrums, Reihe B, vol 69. University of Göttingen

Joyce PM (1998) Growing broadleaves: Silvicultural guidelines for ash, sycamore, wild cherry, beech and oak in Ireland. COFORD, Dublin

Kimmins JP (1977) Evaluation of the consequences for future tree productivity of the loss of nutrients in whole-tree harvesting. For Ecol Manag 1:169-183. doi:10.1016/0378-1127(76)90019-0

Kraft G (1884) Beiträge zur Lehre von den Durchforstungen, Schlagstellungen und Lichtungshieben. Klindeorth

Kurz WA, Dymond CC, White TM, Stinson G, Shaw CH, Rampley GJ, Smyth C, Simpson BN, Neilson ET, Trofymow JA, Metsaranta J, Apps MJ (2009) CBMCFS3: a model of carbon-dynamics in forestry and land-use change implementing IPCC standards. Ecol Model 220:480-504. doi:10.1016/j. ecolmodel.2008.10.018

Makundi W, Sathaye J (2004) GHG Mitigation Potential and Cost in Tropical Forestry — Relative Role for Agroforestry. In: Wassmann R, Vlek P (eds) Tropical Agriculture in Transition - Opportunities for Mitigating Greenhouse Gas Emissions? Springer Netherlands, pp 235-260. doi: 10.1007/978-94-0173604-6_13

Maniatis D, Saint André L, Temmerman M, Malhi Y, Beeckman H (2011) The potential of using xylarium wood samples for wood density calculations: a comparison of approaches for volume measurement. iForest - Biogeosci Forest 4(4):150-159. doi:10.3832/ifor0575-004

Masera OR, Garza-Caligaris JF, Kanninen M, Karjalainen T, Liski J, Nabuurs GJ, Pussinen A, de Jong BHJ, Mohren GMJ (2003) Modeling carbon sequestration in afforestation, agroforestry and forest management projects: the CO2FIX V 2 approach. Ecol Model 164(2-3):177-199. doi:10.1016/S0304-3800(02)00419-2

Montagnini F, Nair PKR (2004) Carbon sequestration: an underexploited environmental benefit of agroforestry systems. Agroforest Syst 61-62(1):281-295. doi:10.1023/B:AGFO.0000029005.92691.79

Morhart C, Sheppard J, Spiecker H (2013) Above ground leafless woody biomass and nutrient content within different compartments of a $P$. maximowicii $\times P$. trichocarpa poplar clone. Forests 4(2):471-487. doi:10.3390/f4020471

Morhart C, Douglas GC, Dupraz C, Graves AR, Nahm M, Paris P, Sauter UH, Sheppard J, Spiecker H (2014) Alley coppice-a new system with ancient roots. Ann For Sci 71(5):527-542. doi:10.1007/s13595-014-0373-5

Nair PKR, Mohan Kumar B, Nair VD (2009) Agroforestry as a strategy for carbon sequestration. J Plant Nutr Soil Sci 172(1):10-23. doi:10.1002/jpln.200800030 
Nair PKR, Nair VD, Kumar BM, Showalter JM (2010) Carbon sequestration in agroforestry systems. Adv Agron 108:237-307. doi:10.1016/S00652113(10)08005-3

Otter M (1954) Le cerisier, son importance sylviculturale et son traitement. Schweiz Forstw 105(12):697-711

Parresol BR (1999) Assessing tree and stand biomass: a review with examples and critical comparisons. For Sci 45(4):573-593

Parresol BR (2001) Additivity of nonlinear biomass equations. Can J For Res 31(5):865-878. doi:10.1139/x00-202

Peichl M, Thevathasan NV, Gordon A, Huss J, Abohassan R (2006) Carbon sequestration potentials in temperate tree-based intercropping systems, Southern Ontario, Canada. Agroforest Syst 66(3):243-257. doi:10.1007/s10457005-0361-8

Picard N, Saint-André L, Henry M (2012) Manual for building tree volume and biomass allometric equations: from field measurement to prediction. Food and Agricultural Organization of the United Nations and Centre de Coopération Internationale en Recherche Agronomique pour le Développement, Rome, Montpellier

Pretzsch H (2010) Forest dynamics, growth and yield: from measurement to model. Springer, Berlin Heidelberg

Pryor SN (1988) The silviculture and yield of wild cherry. Forestry Commission bulletin, vol. 75. Her Majesty's Stationery Office, London

R Core Team (2015) R: A language and environment for statistical computing. R Foundation for Statistical Computing. Vienna, Austria. Available online at http://www.R-project.org/

Röös M (1994) Ertragstafel für Wildkirsche (Prunus avium L.) in NordwestDeutschland. Allg Forst Jagdztg 165(1):13-18

Roxburgh SH, Paul Kl, Clifford D, England, JR, Raison RJ (2015) Guidelines for constructing allometric models for the prediction of woody biomass: How many individuals to harvest? Ecosphere 6(3):art38. doi: 10.1890/ES14-00251.1

Savill PS (1991) The silviculture of trees used in British forestry. CAB International, Wallingford

Sharrow SH, Ismail S (2004) Carbon and nitrogen storage in agroforests, tree plantations, and pastures in western Oregon, USA. Agroforest Syst 60(2):123130. doi:10.1023/B:AGFO.0000013267.87896.41

Singh P, Lodhiyal LS (2009) Biomass and Carbon Allocation in 8-year-old Poplar (Populus deltoides Marsh) Plantation in Tarai Agroforestry Systems of Central Himalaya, India. New York Sci J 2(6):49-53

Spiecker H (2006) Minority tree species-a challenge for multi-purpose forestry. In: Diaci J (ed) Nature-based forestry in Central Europe: Alternatives to industrial forestry and strict preservation. Biotechnical Faculty, Department of Forestry and Renewable Forest Resources, Ljubljana, pp 47-59

Spiecker M, Spiecker H (1988) Erziehung von Kirschenwertholz. AFZ 43(20):562-565

Spiecker M (1994) Wachstum und Erziehung wertvoller Waldkirschen. Forstliche Versuchs- und Forschungsanstalt Baden-Württemberg, Freiburg, Germany

Springmann S, Rogers R, Spiecker H (2011) Impact of artificial pruning on growth and secondary shoot development of wild cherry (Prunus avium L.). For Ecol Manag 261(3):764-769. doi:10.1016/j.foreco.2010.12.007

Sprugel DG (1983) Correcting for bias in log-transformed allometric equations. Ecology 64(1):209-210. doi:10.2307/1937343

Thies M, Hein S, Spiecker H (2009) Results of a Questionnaire on Management of Valuable Broadleaved Forests in Europe. In: Spiecker H, Hein S, MakkonenSpiecker K, Thies M (eds) Valuable broadleaved forests in Europe. Brill, Leiden, Boston, pp 27-42

Thomas SC, Martin AR (2012) Carbon content of tree tissues: a synthesis. Forests 3(2):332-352. doi:10.3390/f3020332

Toader E (2009) Determination of bark's thickness in wild cherry (Prunus avium L.) at Arad Forest Authority. Studia Universitatis "Vasile Goldis" Seria Stiintele Vietii (Life Sciences Series) 19(2):365-371

Uri $V$, Tullus H, Lõhmus K (2002) Biomass production and nutrient accumulation in short-rotation grey alder (Alnus incana (L.) Moench) plantation on abandoned agricultural land. For Ecol Manag 161(1-3):169-179. doi:10.1016/S0378-1127(01)00478-9

Uri V, Vares A, Tullus H, Kanal A (2007) Above-ground biomass production and nutrient accumulation in young stands of silver birch on abandoned agricultural land. Biomass Bioenerg 31(4):195-204. doi:10.1016/j.biombioe. 2006.08.003

van Laar A, Akça A (1997) Forest mensuration, 1st edn. Cuvillier, Göttingen
VDLUFA (Association of German Agricultural Analytic and Research Institutes) (1976) Methods Book III "The chemical analysis of feedstuffs " (1st-8th supplement delivery), 3rd edn. VDLUFA-Verlag, Darmstadt

VDLUFA (Association of German Agricultural Analytic and Research Institutes) (1991) Methods Book I "Soil Analysis" (1st-6th supplement delivery), 4th edn. VDLUFA-Verlag, Darmstadt

VDLUFA (Association of German Agricultural Analytic and Research Institutes) (2011) Methods Book VII "Environmental Analytics", 4th edn. VDLUFA-Verlag, Darmstadt

Wang JR, Letchford T, Comeau P, Kimmins JP (2000) Above- and below-ground biomass and nutrient distribution of a paper birch and subalpine fir mixedspecies stand in the Sub-Boreal Spruce zone of British Columbia. For Ecol Manag 130(1-3):17-26. doi:10.1016/S0378-1127(99)00193-0

Wang JR, Zhong AL, Simard SW, Kimmins JP (1996) Aboveground biomass and nutrient accumulation in an age sequence of paper birch (Betula papyrifera) in the Interior Cedar Hemlock zone, British Columbia. For Ecol Manag 83(1-2):27-38. doi:10.1016/0378-1127(96)03703-6

Wassenberg M, Chiu H, Guo W, Spiecker H (2015) Analysis of wood density profiles of tree stems: incorporating vertical variations to optimize wood sampling strategies for density and biomass estimations. Trees 29(2):551-561. doi:10.1007/s00468-014-1134-7

Wright TW, Will GM (1958) The nutrient content of Scots and Corsican pines growing on sand dunes. Forestry 31(1):13-25. doi:10.1093/forestry/31.1.13

Zianis D, Muukkonen P, Mäkipää R, Mencuccini M (2005) Biomass and stem volume equations for tree species in Europe. Silva Fenn Mon 4:1-63

Zeng WS, Tang SZ (2011) Bias Correction in Logarithmic Regression and Comparison with Weighted Regression for Nonlinear Models. Nature Preceedings. doi.10.1038/npre.2011.6708.1

\section{Submit your manuscript to a SpringerOpen ${ }^{\circ}$ journal and benefit from:}

- Convenient online submission

- Rigorous peer review

- Immediate publication on acceptance

- Open access: articles freely available online

- High visibility within the field

- Retaining the copyright to your article

Submit your next manuscript at $>$ springeropen.com 